\title{
Asteraceae in Flora of Argunskiy Biological Reserve
}

\author{
Umarov M.U. \\ Kh. Ibragimov Complex Institute of the Russian \\ Academy of Sciences \\ Grozny, Russia \\ umarovbiolog@mail.ru
}

\author{
Dulaev H.D. \\ Chechen State Pedagogical Institute \\ Grozny, Russia \\ dulaev.havagi@mail.ru
}

\author{
Umarov R.M. \\ Department of biological and medical research \\ Academy of Sciences of Chechen Republic \\ Grozny, Russia \\ umrusmuh@mail.ru \\ Mamadzhanov R.H. \\ The Peoples' Friendship University of Russia \\ Moscow, Russia \\ Daddy_roma@mail.ru
}

\author{
Karataev L.S. \\ Department of biological research \\ Kh. Ibragimov Complex Institute of the Russian Academy of Sciences \\ Grozny, Russia \\ kniiran@mail.ru
}

\begin{abstract}
A study of flora in Argunskiy Biological Reserve in Chechen Republic, with over 490 species of vascular plants. Asteraceae family was investigated in particular detail, including 60 species and 38 genera. Centaurea is presented in 7 species, Artemisia, Inula - 5 species each; 3 species each of Cirsium and Hieracium genera, 2 species each - Ambrosia, Achillea, Arctium, Carduus, Matricaria, Petasites, Senecio, Sonchus, Xanthium. The abovementioned genera total to 42 species and $67.7 \%$ of the family. 20 species with a sole genus constitute $32.3 \%$. The family is represented by species of various geographic origin - 6 geotypes and 20 geo-elements with significant prevalence of golarctic(35, $4 \%)$ and boreal $(33.8 \%)$ geotypes. Species useful for various purposes are listed. Rare and protected species of the family are indicated.
\end{abstract}

Keywords - Chechen republic, Argunskiy Biological Reserve, flora, Asteraceae, benefits, rare species, protection, reproduction.

\section{INTRODUCTION}

Asteraceae family (Asterales) is the largest family of flowering plants, with over 20000 species and 1150-1300 genera [1]. Asteraceae species have a cosmopolitan distribution and can be found in all continental zones. [2]. They play a major role in forming phytocenosis and plant cover. Asteraceae is an economically important family. Argunskiy Biological Reserve was founded in 1977 in floodplain forest of the rivers Sunzha, Argu and Dzhalka, on the area of Groznensiy and Gudermesskiy districts of Chechen Republic. Forest areas constitute 8.7 thousand hectares of the total area (15 thousand hectares). Gardens, fields, haylands, vegetable gardens and pastures constitute 6.3 thousand hectares [3]. Various habitats and ecological niches are presented on the area of the reserve. Focused research of plant cover and flora is being carried out. Preliminary results identified approximately 500 species of higher vascular plants from 96 families in the flora of the reserve. We focus our research on the analysis of the family containing the largest number of species and genera. Asteraceae.

\section{METHODS AND MATERIALS}

We have been investigating flora and vegetation of Agunskiy Biological Reserve since 2015. During this period, we attended all accessible areas and habitats, populated by various phytocenoses, in autumn and spring. We covered and herborized all the species we came across. To specify the identification, we used «Identification of Kavkaz plants» by A. A. Grossgeim, [4], «Flora of the North Caucasus» by Galushko [5], bulletin by S. K. Czerepanov [6]. We compiled a preliminary systematic list of flora that includes over 490 species of vascular plants. A more detailed research was performed for one of the largest families in the reserve Asteraceae. We accounted for systematic and quantative composition and geographical elements by N. N. Portenier [7], their ratio, distribution of species on the territory of the reserve, their useful properties. Resource potential of the species is borrowed from A. A. Grossgeim, [8], E. V. Wolf, O. F. Maleeva [9], H.A. Hoppe. [10], J. Harvey [11], N. I. Maznev [12], «Plant resources of USSR» [13], M. U.Umarov and M. A. Taimusov [14] et al. The following types of species are identified by their resource potential: medicinal $(\mathrm{M})$, food $(\mathrm{N})$, honey $(\mathrm{H})$, decorative $(\mathrm{D})$, containing tannin $(\mathrm{T})$, feed $(\mathrm{F})$, dyeing $(\mathrm{C})$, used for coffee surrogate $(\mathrm{Cf})$, insecticides, suitable to deter insects (I) and arthropods - repellents (A), weeds (W), poisonous for humans or animals $(\mathrm{P})$, allergenic $(\mathrm{Al})$, aromatic $(\mathrm{Ar})$, rubbercontaining $(\mathrm{R})$, oil-bearing $(\mathrm{O})$. The distribution of species outside the reserve is indicated according to altitude zones of the Chechen Republic. The results of research and analysis of scientific sources are reflected in tables 1 and 2.

\section{RESULTS}

According to our preliminary data, the flora of the biological reserve contains about 500 species of flowering plants from 107 families, Asteraceae family being the largest in terms of genera (34) and species I (62). Centaurea is presented by the largest amount of species -7 species, Artemisia, Inula by 5 species each; 3 species each of Cirsium and Hieracium genera, 2 species each - Ambrosia, Achillea, Arctium, Carduus, 
Matricaria, Petasites, Senecio, Sonchus, Xanthium. The abovementioned genera total to 42 species and $67.7 \%$ of the family. 20 species with a sole genus constitute $32.3 \%$. The family is represented by species of various geographic origin 6 geotypes and 20 geo-elements with significant prevalence of golarctic and boreal geotypes (33.9\% each).

The representation of Asteraceae in the reserve by different geotypes, geo-elements and 62 species indicates its phytodiversity. Analysis of the spectrum of geographic elements indicates prevalence of golarctic (22 species, 35.4\%) and boreal geotypes (21 species, 33.8\%). The following geotypes were identified, in descending order: adventive ( 8 species, $-12.9 \%$ ), ancient mediterranean ( 6 species- $9.6 \%$ ), connecting ( 4 species - $6.4 \%)$, multiareal ( 1 species $-1,6 \%)$. However, the distribution of geoelements in geotypes is uneven.

Palearctic geoelements significantly prevail in golarctic geotype $(81.8 \%)$, where areals cover moderate and subtropical areas of the Old World Golarctic (Eurasia and Africa), with only $18.2 \%$ of golarctic. Boreal geotype contains 7 geoelements with significant prevalence of pontic-southern Siberian (28.6\%), typical for Eurasian steppe [15] and euroSiberian $(23.8 \%)$. Caucasian $(14.3 \%)$ euro-caucasian and contic geoelement $(9.5 \%)$ are represented on much rarer basis. In adventive geotype, 7 out of 8 total species are non-native, introduced from North America (Ambrosia trifida, Ambrosia artemisifolia, Erigeron canadensis, Matricaria matricarioides, Phalachroloma annuum, Xanthium spinosum, Xanthium strumarium) and only one (Sigesbeckia orientalis) is from Southeast Asia. As for connecting geotype, which accounts only for 4 species, all geoelements - Sub-Mediterranean., SubCaucasian, subpontic and subtourian - are presented equally infrequent - by 1 species.

The fact that the family contains the species of different geographic origin indicates multi-directional migration routes during the florogenesis process.

There are a lot of valuable species among the recorded 62 species of Asteracxeae family. The family is plentiful in medicinal plants. The majority of them is used in scientific medicine and folk medicine: common yarrow (Achillea millefolium), common wormwood (Artemisia vulgaris), Common chicory (Cichorium inthybus), Elecampane - (Inula helenium), wild camomile (Matricaria recutita), three-lobe beggarticks (Bidens tripartita), cornflower (Centaurea cyanus), coltsfoot (Tusillago farfara), dandelion (Taraxacum officinale), greater burdock (Arctium lappa) and others.

The following species are suitable for eating (as salads, dressings or spices): Spanish salsify (Scorzonera hispanika) roots and green leaves, dandelion (Taraxacum officinale) leaves, roots, flower stalks, greater burdock - fresh stems and roots, welted thistle (Carduus crispus) - green leaves, nodding thistle (C. nutans) - green shoots, leaves, receptacle, spiny cocklebur (Xanthium spinosum) - green leaves, and others.

The following are considered good nectar-bearing plants: species of genera plumeless thistles (Carduus), thistle (Cirsium), burdock (Arctium), centory (Centaurea), dandelion, common cocklebur (Xanthium strumarium), whereas yarrow
(Achilea), butterburs species (Petasites), hawkweed (Hieracium echinoides), spanish salsify, species of the Senecio genus are considered secondary.

The following are distinguished as ornamental plants: goldenrods (Solidago virgaurea), wormwood, yarrow, oxeye daisy (Leucanthemum vulgare) bonesets (Eupatorium cannabinum), species of Innula вIDы, common chicory, cornflower, Centaurea ruthenica, yellow star-thistle (Centaurea solstitialis), annual everlasting (Xeranthemum annuum), glandular globe-thistle (Echinops spaerocephalus) and others.

Many composite flowers can be used for dyeing wool, fabrics, and paper in different colors and shades. Suitable as yellow dye: chamomile, oxeye daisy, European goldenrod, common cocklebur; horse-heal is used for purple color. Threelobe beggarticks can be used to dye wool and silk in yellow, beige and brown shades, sweet wormwood (Artemisia annua) for lemon-yellow color. Cornflowers can color fabrics blue. Leaves and stems of Eupatorium cannabinum and dry roots of elecampane are used for blue coloring. Common cocklebur dyes wool in yellow and green. Stems, leaves and flowers of Groundsel (Senecio vulgaris) and glandular globe-thistle are suitable for green color.

The following oil-bearing plants can be mentioned: woolly distaff thistle (Carthamus lanatus), cotton thistle (Onopordum acanthium), common cocklebur.

Yarrow, common ragweed, absinthe wormwood (Artemisia absinthium) and common wormwood (Artemisia vulgaris), burdock, horseweed, and chamomile contain essential oils.

Common ragweed contains a dangerous allergic agent, whereas common ragweed, yarrows, species of wormwood genera are anthelmintic.

Among the representatives of sunflower family in the reserve are also feeding plants, spices and aromatic plants (yarrow, wormwood, horse-heal), rubber-plants (Jurinea arachnoidea, rush skeletonweed (Chondrilla juncea), horseweed (Erigeron canadensis)

Some species contain vitamins: yarrow, common nipplewort - vitamin A; burdock, common chicory, horseweed, rush skeletonweed, cotton thistle (Onopordum acanthium), common cocklebur - vitamin C; common wormwood, European goldenrod, coltsfoot chamomile - vitamins A and C.

Burdock, common chicory, spanish salsify and dandelion are suitable for coffee-like beverages.

Abundance of weeds signifies intensive agricultural activity in the reserve (herding cattle, adjacent fields and settlements): common cocklebur and spiny cocklebur, three-part beggarticks, horseweed, cornflower and low cornflower, common thistle (Cyrsium vulgare), as well as the types of weeds that are hard to eliminate - creeping thistle (Cirsium arvense), blue lettuce (Lactuca tatarica), field milk thistle (Sonchus arvensis), annual fleabane (Phalachroloma annuum), two ragweed (Ambrosia) species. 
TABLE I. Distribution Of ARgunskiy Reserve Flora Among Geographical Belts Of CheChen Republic

\begin{tabular}{|c|c|c|c|c|c|c|c|c|c|}
\hline \multirow{2}{*}{ № } & \multirow{2}{*}{ Name of species } & \multicolumn{6}{|c|}{ Distribution by belt } & \multirow{2}{*}{ Geoelements } & \multirow{2}{*}{ Economic use } \\
\hline & & I & II & III & IV & $\mathbf{v}$ & VI & & \\
\hline 1 & Achillea biebersteinii Afan. & + & + & + & & & & East Ancient Mediterranean & M.F.Cf.Ar.O \\
\hline 2 & A. millefolium L. & + & + & + & & + & & Euro-Siberian. & M.N.D.F.A.O \\
\hline 3 & Ambrosia artemisifolia L. & & & & & & & Adventive. N-American. & M.C.Al \\
\hline 4 & Ambrosia trifida L. & & & & & & & Adventive. N-American. & $\mathrm{W}$ \\
\hline 5 & Arctium lappa L. & + & + & + & & & & Palearctic & M.N.H.D.E.Cf \\
\hline 6 & A. palladinii (Marc.) Grossh. & + & + & + & & & & Caucasian & M.H. \\
\hline 7 & Artemisia absithium L. & + & + & + & & + & & Palearctic & M.N.D.F.Пp.Ar.I.P \\
\hline 8 & Artemisia annua L. & + & + & + & & & & Palearctic & M.D.F.C.I..Ar.Пp \\
\hline 9 & Artemisia austriaca Gacg. & + & + & & + & + & & Pontic-South-Siberian & M.К.О.. \\
\hline 11 & Artemisia taurica Willd. (A. graveolens Minatullaev) & + & + & & & & & Pontic & M.D.K.P.P.O \\
\hline 12 & Artemisia vulgaris L. & + & + & + & & & & Golarctic & M.N.D.K.Сч.I.O. \\
\hline 13 & Aster amelloides Bess. & & + & + & + & & & Pontic-South-Siberian & F.D. \\
\hline 14 & Bidens tripartita L. & & + & + & & & & Multiareal & M.F.C \\
\hline 15 & Carduus crispus L. & + & + & + & + & & & Palearctic & M.N.H.F. \\
\hline 16 & Carduus nutans L. (C. thoermeri Weinm.)- & + & + & + & + & & & Palearctic & M.N.H.F. \\
\hline 17 & Carthamus lanatus $\mathrm{L}$. & + & + & + & & & & $\begin{array}{l}\text { General Ancient } \\
\text { Mediterranean }\end{array}$ & M.N.F.C.Mc \\
\hline 18 & Centaurea cyanus L. & + & + & + & & & & Golarctic & M.H.D.C.W..P \\
\hline 19 & Centaurea depressa Bieb. & + & + & + & & & & East Ancient Mediterranean & M.H.D.W. \\
\hline 20 & Centaurea diffusa Lam. & + & + & + & & & & Pontic & M.H.F.P \\
\hline 21 & Centaurea iberica Trev. ex Spreng & + & + & + & & & & Iranian- Turanian & M.H.F \\
\hline 22 & Centaurea ruthenica Lam. & + & + & + & & & & Sub-turanian & T.H. D.F \\
\hline 23 & Centaurea salicifolia Bieb. & & & + & & & & Subcaucasian & M.F \\
\hline 24 & Centaurea solstitialis L. & + & + & & & & & Iranian- Turanian & M.D.R \\
\hline 25 & Chondrilla juncea L. сІтнIковIDнаР & + & + & + & & & & Submediterranean & M.N.F \\
\hline 26 & Cichorium intybus L. & + & + & + & & & & Palearctic & M.N.H.F.Cf \\
\hline 27 & Cirsium arvense ( L.) Scop. & + & + & & & & & Euro-Siberian & M.N.R.P \\
\hline 28 & Cirsium canum (L.) All. (C. biebersteinii Charadze) & & & & & & & European & N.H.C. \\
\hline 29 & Cirsium vulgare (Savi) Ten. & + & + & + & & & & Palearctic & M.H.C \\
\hline 30 & Echinops sphaerocephalus L. & + & + & + & & & & Pontic South-Siberian & M.N.H.D.T.P. \\
\hline 31 & Erigeron canadensis L. & + & + & + & & & & Adventive. N.American & M.H.F.W \\
\hline 32 & Eupatorium cannabinum L. & + & + & + & & & & Palearctic & M. H.D. W.T.P \\
\hline 33 & Hieracium echioides Lumn. & & + & + & & & & Palearctic & $\mathrm{M}$ \\
\hline 34 & Hieracium pilosella L. & & + & + & & + & + & Euro-Caucasian & M.P \\
\hline 35 & Hieracium umbellatum L. & & + & + & & & & Golarctic & M.H.F. W \\
\hline 36 & Inula aspera Blum. ex Ledeb. & + & + & + & & & & Pontic.- South-Siberian & $\mathrm{M}$ \\
\hline 37 & Inula britannica $\mathrm{L}$. & + & + & + & & & & Palearctic & M.H.F \\
\hline 38 & Inula caspica Blum ex Ledeb. & + & + & & & & & Turanian & M.H.F \\
\hline 39 & Inula germanica L. & + & + & + & & & & Euro Caucasian & M.H.F \\
\hline 40 & Inula helenium L. & + & + & + & & & & Palearctic & M.N.H.D.K.W.Пp \\
\hline 41 & Jurinea arachnoidea Bunge & + & + & + & + & + & & Pontic-South-Siberian & M.F.D.R \\
\hline 42 & Lapsana communis L. & + & + & + & & & & Palearctic & M.N \\
\hline 43 & Leucanthemum vulgare Lam. & & + & + & & + & & Euro-Siberian & M.N.H.D.F.W.I.P \\
\hline 44 & Matricaria matricarioides (Less.) Porter ex Britt. & + & + & & & & & Adventive N-American & M.Al.I. \\
\hline 45 & Matricaria recutita L. & + & + & + & & & & Golarctic & M.F.C.Ar \\
\hline 46 & Onopordum acanthium L. & + & + & + & & & & Palearctic & M.N.H.D.T.F.O \\
\hline 47 & $\begin{array}{l}\text { Phalachroloma annuum (L.) Dumort. (Erigeron annuus (L.) } \\
\text { Pers., Stenactis annua (L.) Cass. }\end{array}$ & + & + & + & & & & Adventive. N-American & D.C \\
\hline 48 & $\begin{array}{l}\text { Petasites albus (L.) Gaerhn. } \\
\end{array}$ & & & + & & & & Caucasian-European & M. H.D. I.R. \\
\hline 49 & Petasites hybridus (L.) Gaerth.,Mey et Schreb. & & + & + & & & & Caucasian-European & M.H.N.F.R \\
\hline 50 & Scorzonera hispanika L. (Sc. taurica Bieb.) & + & + & + & & & & Pontic South-Siberian & M.N.H.F.Cf \\
\hline 51 & Senecio macrophyllus Bieb. & & + & & & & & Caucasian (eucaucasian) & $\mathrm{F}$ \\
\hline 52 & Senecio vulgaris L. & + & + & + & & & & Palearctic & M.C.W.R \\
\hline 53 & Sigesbeckia orientalis L. & + & + & + & & & & Adventive :S.E.Asia & M.P \\
\hline 54 & Silubum marianum (L.) Gaertn. & + & + & + & & & & Palearctic & M.П.D.F.D.O \\
\hline 55 & Solidago vulgaurea $\mathrm{L}$. & & & + & & + & + & Euro-Siberian & M.H.P. (sheep) \\
\hline 56 & Sonchus arvensis L. & + & + & + & & & & Palearctic & M.N.H.F \\
\hline 57 & Sonchus palustris L. & + & + & + & & & & Palearctic & M.N.H.F \\
\hline 58 & Taraxacum officinale Wigg. & + & + & + & & & & Palearctic & M.N.Пp.A.Cf.H.I.F \\
\hline 59 & Tussilago farfara L. урож.:8-1024 ц/га & + & + & + & & & & Euro-Siberian & M.H.F \\
\hline 60 & Xanthium spinosum $L$. & + & + & + & & & & $\begin{array}{l}\text { Adventive. South-Siberian } \\
\text { rudimental }\end{array}$ & C.M.N.P.(for cattle) \\
\hline 61 & Xanthium strumarium L. & + & + & + & & & & Adventive. South-Siberian & M.H.F.T.C.W.P \\
\hline 62 & Xeranthemum annuum L. & + & + & + & & & & Subpontic & M.D.F \\
\hline & Total & 46 & 52 & 49 & 5 & 5 & 5 & & \\
\hline
\end{tabular}


TABLE II. RATIO OF GEOTYPES AND GEOELEMENTS OF ASTERACEAE FAMILY IN ARGUNSKIYBIOLOGICAL RESERVE

\begin{tabular}{|c|c|c|c|}
\hline \multirow[t]{2}{*}{ Geotypes and geoelements } & \multirow{2}{*}{$\begin{array}{l}\text { Number } \\
\text { of species }\end{array}$} & \multicolumn{2}{|c|}{$\%$ in } \\
\hline & & family & Geotype \\
\hline MULTIAREAL & 1 & 1,6 & 100 \\
\hline Multiareal & 1 & 1.6 & 100 \\
\hline GOLARCTIC & 22 & 35.4 & 100 \\
\hline Golarctic & 4 & 6.4 & 18.2 \\
\hline Palearctic & 18 & 29 & 81.8 \\
\hline BOREAL & 21 & 33.8 & 100 \\
\hline Euro-Siberian & 5 & 8.1 & 23.8 \\
\hline Euro-Caucasian & 2 & 3.2 & 9.5 \\
\hline European & 1 & 1.6 & 4.8 \\
\hline Caucasian-European & 2 & 3.2 & 9.5 \\
\hline Pontic South-Siberian & 600 & 9.7 & 28.6 \\
\hline Pontic & 2 & 3.25 & 9.5 \\
\hline Caucasian & 3 & 4.8 & 14.3 \\
\hline ANCIENT MEDITERRANEAN & 6 & 9.6 & 100 \\
\hline General Ancient Mediterranean & 1 & 1.6 & 16.7 \\
\hline East Ancient Mediterranean & 2 & 3.2 & 33.3 \\
\hline Iranian-turanian & 2 & 3.2 & 33.3 \\
\hline Turanian & 1 & 1.6 & 16.7 \\
\hline CONNECTIVE & 4 & 6.4 & 100 \\
\hline Submediterranean & 1 & 1.6 & 25 \\
\hline Subcaucasian & 1 & 1.6 & 25 \\
\hline Subpontic & 1 & 1.6 & 25 \\
\hline Subturanian & 1 & 1.6 & 25 \\
\hline ADVENTIVE & 8 & 12.9 & 100 \\
\hline Adventive & 8 & 12.9 & 100 \\
\hline
\end{tabular}

The only Red book species in the reserve is horse-heal (Inula helenium) [14]. However, some species are rare for this territory or inconsiderable in number, such as yellow starthistle(Centaurea solstitialis), oxeye daisy (Leucanthemum vulgare),pineappleweed (Matricaria matricarioides), Queen Anne's thistle (Cirsium canum), Senecio macrophyllus, milk thistle (Silubum marianum), coltsfoot (Tussilago farfara).

Research of the plant cover of the reserve continues, and it is likely that it will allow us to add some new species to the list. In general, the reserved is characterized by abundant various habitats and ecological niches, significant diversity of flora, abundance of economically valuable species of different geographic origin. Conservation, reproduction and protection of existing biodiversity are among the most pivotal objectives of the state biological reserve, focused on sustainable functioning of its natural ecosystems.

\section{CONCLUSION}

We identified 62 species from 34 genera of Asteraceae family in Argunskiy biological reserve (Chechen republic)

The largest genera are: Centaurea is presented in 7 species, Artemisia, Inula -5 species each; 3 species each of Cirsium and Hieracium genera, 2 species each - Ambrosia, Achillea, Arctium, Carduus, Matricaria, Petasites, Senecio, Sonchus, Xanthium. The abovementioned genera total to 42 species and $67.7 \%$ of the family. 20 species with a sole genus constitute $32.3 \%$.
The family is represented by species of various geographic origin - 6 geotypes and 20 geo-elements with significant prevalence of golarctic $(35.4 \%)$ and boreal geotypes $(33.8 \%)$.

The family is rich in valuable plants used for different purposes: medicinal plants, adornment (decorative) plants, plants that could be used as food, honey plants, dyeing plants, animal feed species, essential-oil plants and others.

Special attention and reproduction is required for the Red Book species horse-heal (Inula helenium), which is a valuable medicinal plant, and for some species that are rare for this territory or inconsiderable in number, such as yellow starthistle(Centaurea solstitialis), oxeye daisy (Leucanthemum vulgare),pineappleweed (Matricaria matricarioides), Queen Anne's thistle (Cirsium canum), Senecio macrophyllus, milk thistle (Silubum marianum), coltsfoot (Tussilago farfara).

The studies are focused on a detailed research of plant cover (flora and vegetation) in order to develop a complex approach for conservation, protection and reproduction of biodiversity and ecosystems in a specially protected natural area.

\section{References}

[1] M.E. Kirpichnikov, Order of Asterales

[2] A.L. Tahtadzhan, "System and phylogeny of flowering plants", M.L.Nauka, 1966, p. 612.

[3] M.U. Umarov, M.A. Taysumov, H.D. Dulaev, "Rare types of flora of the Argunsky reserve", Materials, [XIX intenational scientific conference with scientific school for young scientists, "Biological diversity of the Caucasus and southern Russia" (Makhachkala, 4-7 November, 2017), vol. 1, Makhachkala, 2017, pp. 328-332]

[4] A.A. Grossgeim, "Identificator of Kavkaz plants", Moskow: Sovetskaya nauka, 1949, p. 376.

[5] A.I. Galushko, "Flora of the North Causasus", 3 volumes, vol. 3 , Izdatelstvo Rostovskogo universiteta, 1980, p. 328

[6] S.K. Czerepanov, "Vascular Plants of Russia and Adjacent States", Cambridge University Press, 1995, p. 516

[7] N.N. Portenier, A.K. Sostyu et al., "Flora and botanical geography of the North Caucausus", M.: KMK, 2012, p. 294.

[8] A.A. Grossheim, "Plant riches of the Caucasus", ed. A.I. Takhtadzan, M., 1952, p. 632.

[9] E.V. Wolf, O.F. Maleeva, "World resources of useful plants”, Directory, L.: Science, 1969 , p. 566.

[10] H.A. Hoppe, "Drogenkunde", Bd. 1-2, Berlin; New York, 1975, Bd 1, p 1311.

[11] J. Harvey, Herbs, London, 1976, p. 96

[12] N.I. Maznev, "Medicinal plants: 15,000 names of medicinal plants, mixes and recipes", Description, properties, use, contraindications, M.: OOO IKTC "Lada", LLC ID "Ripol Classic", LLC "House XXI Century", 2006, p. 1056

[13] "Plant resources of the USSR: Flowering plants, their chemical composition", use; Family Asteraceae, SPb.: Science, 1993, p. 352

[14] M.U. Umarov, M.A. Taysumov, “Abstract of the flora of the Chechen Republic", Grozny, 2011,p. 152.

[15] "The main features of the botanical-geographical separation of the USSR and neighboring countries", Botany problems, vol. 1, M.-L.: AN SSSR, 1950 , p. 530-548.

[16] "The Red Book of Chechen respublic: rare and endangered spicies of plants and animals" (editor - Umarov M. U.), Grozny, 2007, p. 432.

[17] M.A. Taysumov, "Caryopphylloitae subfamily in flora of the North Caucasus. Grozny: Chechen Academy os Science", 2011, p. 35 